\title{
1. Introduction: origins and evolution of environmental policies - state, time and regional experiences
}

\author{
Tadayoshi Terao and Tsuruyo Funatsu
}

The pursuit and achievement of industrial development balanced with maintaining good environmental quality is no easy feat. In many cases, early environmental policy formation went wrong. Most developing countries confronting the dilemma between economic development and the environment have difficulty in achieving balanced economic development (O'Conner 1994), while some developed countries may have begun adjustment toward more balanced development (Terao and Otsuka 2007). In fact, some successful cases of environmental policies and institutions tend to be found in developed countries rather than in developing countries. However, the relations between policy outcome and the level of economic development is not so direct, as it is not always the case that all the environmental policies in developed countries come up with successful implementation, nor that developing countries all fail in their efforts in environmental protection.

In this volume, each chapter takes a historical approach, especially a "path dependence" perspective to focus on the trajectory of changes in which things happen, to analyze the process of success or failure in environmental policy formation, each paying special attention to the role of the state. In this chapter, we focus on why a historical approach is required and how the state matters in the analysis of environmental policy formation, both in developed and developing countries.

\subsection{EMERGENCE OF ENVIRONMENTAL ISSUES IN LATECOMER PUBLIC POLICY}

We begin by summarizing the origins of environmental issues that emerged in the wake of resource management issues during the 1960s and 1970s. Through a brief survey of earlier studies, this chapter points out that the recognition and identification of "the environment" came about during the process of industrialization. Environmental policies emerged as latecomer public policies, and 
thus a historical approach with special attention given to the order of policy formation is useful for our analysis.

From a historical perspective, resource management problems were first recognized as an important issue to tackle prior to the identification of "the environment" (Oikawa 2013; Sato 2013, pp. 4-8). To conserve resources, the state, community, and private ownership assumed the roles of professionals/ government, citizens, and markets, respectively. Natural resources, such as forest and aquatic resources, were managed mostly by local communities. Meanwhile, prior to nationalization, land and mineral resources were managed by private owners. Due to changes in the development of technology and resource management, the state often came to replace the community in the role of utilizing and managing resources, as typically seen in the case of irrigation (see Sato 2019 and Chapter 6 in this volume).

During the 1960s, when rapid industrialization took place in today's developed countries, environmental issues started to be framed as a separate social problem, apart from resource management. Starting in the mid-1970s, developing countries also began to embrace the concept of addressing environmental concerns via development-related public policy. Not only issues such as industrial pollution and waste management, but also the conservation of water, forest, land, and energy resources came to be regarded as an important aspect of environmental issues in countries undergoing rapid industrialization.

Meanwhile, the existing problem of natural resource depletion came to be framed as an environmental consequence of rapid industrialization. Thus, water and air pollution and industrial waste issues began to be defined as environmental problems and natural resource depletion was redefined as an environmental issue rather than a resource conservation problem. Furthermore, these natural resource problems gradually came to be linked to global environmental issues, such as global warming, transboundary pollution (e.g., acid rain, PM 2.5 ), and ozone layer depletion, in the 1980s. Thus, the scope of environmental issues was expanded, and environmental policy emerged as a new domain of public policy only after industrialization took place and natural resource depletion was redefined. This explains the latecomer position of environmental public policy.

\subsection{STAKEHOLDERS OF ENVIRONMENTAL ISSUES AND THE ROLES OF THE STATE}

The new and vague concept of "the environment" was a latecomer issue in the area of public policy, and therefore the formation of environmental policy required coordination and negotiations among various stakeholders, including government agencies, business enterprises, and citizens (e.g., local residents, non-governmental organizations (NGOs), and social movement organiza- 
tions). In this section, we summarize the stakeholder problem of environmental issues from earlier studies.

In "The Tragedy of the Commons," which presented an early attempt at resource management analysis, Garrett Hardin argues that resource usage problems occur as a result of a lack of incentive mechanism that motivates individual resource consumers to bear the external costs of resource usage (Hardin 1968). In places where communities have played important roles in managing common resources, nationalization of such resources by the state often resulted in depriving local incentives to sustain them (Sato 2019).

In contrast, the newly emerging "environmental issues" were broader and vaguer and required state involvement, framing the problem as a state policy issue. The characteristics of environmental issues themselves are closely related to state involvement. A comparison between resource management and environmental issues more clearly highlights the differences between the two concepts. For instance, resources generally have a user that extracts economic value or, most commonly, resources are owned or controlled by someone able to manage or preserve them. However, the environment forms a boundary between economic society and nature itself, and is necessary for human survival. But the environment has no specific owners or pressure groups acting on its behalf. Although the environment is related to all human social and economic activities, it does not directly produce specific value per se and has only a broad, vague relationship with human society at large (Terao 2013). While we may not always realize the importance of the environment, it is loosely connected to the interests of many sectors of society and its stakeholders. Thus, it is indispensable for the state to coordinate and mediate these various interests among members of society when implementing environmental policies.

In his book, The Politics of the Earth, Dryzek points out that the role of the state (professionals/government) is central to solving environmental issues, while that of the market is limited. Specifically, among the three main stakeholders in environmental problems (professionals/government, citizens, and markets), the roles of professionals have been regarded as critical because command of technology and scientific knowledge are essential to problem-solving (Dryzek 1997, pp. 61-62).

Moreover, the arguments on environmental governance regard environmental policy formation as a process of coordination and negotiation among various government bodies, citizens, and business enterprises (industrial organizations and market participants), which is able to incorporate various interests and values among stakeholders related to natural resources and the environment (Bridge and Perreault 2009; Lemos and Agrawal 2006). In this context, this volume focuses on the process of coordination and negotiation involved in policy formation by adopting a historical approach with special attention given to the role of the state. 


\subsection{ENVIRONMENTAL POLICY AND PATH DEPENDENCE FROM A HISTORICAL PERSPECTIVE}

Environmental policies are often developed after other public policies have been implemented. Because the policy formation process is often path dependent, meaning that newly formulated policies are often framed by existing public policies, we need to investigate the features of environmental policies with a special focus on the historical backgrounds of the policies.

Pierson (2004) addressed the importance of long-term observation and analysis of the historical backgrounds for social policy research. According to Pierson (2004), most existing policy research has not taken a long-range perspective; instead, it has tended to focus only on the several years before and after the institutionalization of the policies and to point out the factors that facilitated the enactment. This "snapshot" type of research does not specify the structural factors that drive policy formulation. Historical and dynamic analysis is needed for productive policy studies. Kay (2005) also signifies the usefulness of the path dependency approach in policy studies, explaining that "a process is path dependent if initial moves in one direction elicit further moves in that same direction" (Kay 2005, p. 553).

The investigation of resource conservation and environmental problems requires long-term analysis, and these issues emerged as a new domain of public policy only after the policy developed and natural resource depletion was redefined. At the beginning, environmental policy formation often entailed "innovation" of concepts by applying new definitions to old problems related to contamination and resource use in many countries (see Chapters 2, 7 , and 8 in this volume). However, when new environmental policies are made or when related organizations are established, policy options are sometimes limited by earlier development and resource policies (see Chapters 3 and 5 in this volume). Due to the latecomer position of environmental policy, its formation process has a strong path dependence, and issues of timing and sequence of events matter tremendously because the framing of environmental policy sometimes needs to be adjusted under constraints. Analyses of causal relationships sometimes fail to pay attention to these sequences of decisions in policy formation processes and may ignore many important structural conditions prior to a change in policy. Policy systems and institutions change over time, not by the design of a rational actor but as a reflection of the various decisions made over time.

This volume grew out of this perspective, and Chapter 2 presents the idea that difficulties in institutionalizing industrial development balanced with environmental quality are partly derived from the latecomer features of envi- 
ronmental policy. This tendency is especially evident in developing countries that prioritize economic development over environmental protection (Terao 2013). Regarding the concept of the "advantage of backwardness" in the area of development economics (mentioned in Chapter 2), our case studies emphasize the "disadvantage of economic backwardness" in developing countries in the field of environmental policy over the advantage of economic backwardness.

\subsection{MAJOR FINDINGS FROM EACH CHAPTER AND A SUMMARY}

To elucidate the specific difficulties of environmental policy formation, this volume takes up cases from both developed and developing countries, and draws contrasts between successful environmental policies in developed countries (see Chapters 7 and 8 on the United States and Germany, respectively) and those with limited success in developing countries (see Chapters 3 to 5 on China, Taiwan, and Thailand) (Figure 1.1). All the chapters on policy formation examine the situation from a path dependence perspective and clarify problems associated with diffused authority and its integration within the government agencies concerned with environmental policy.

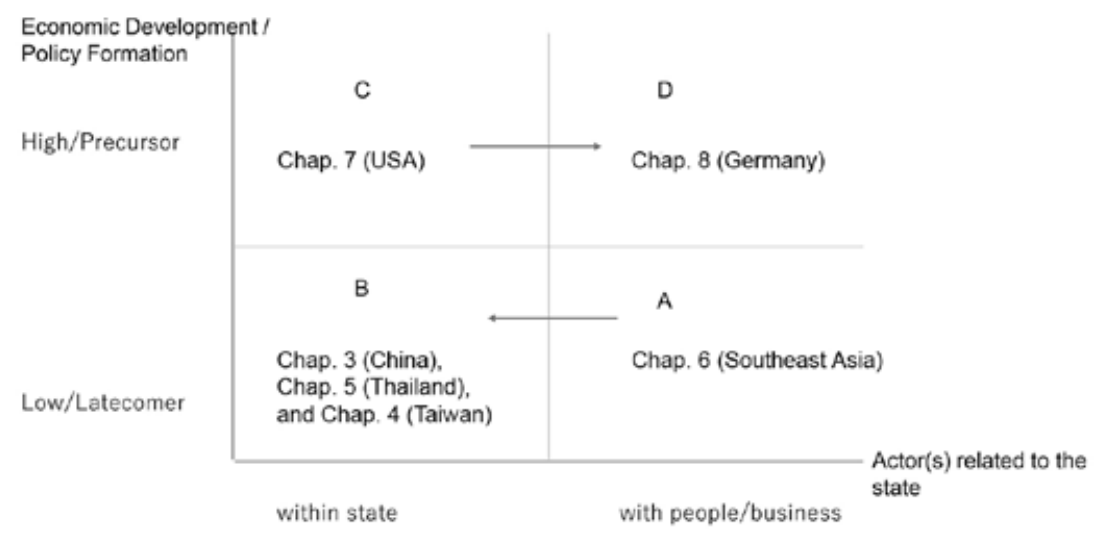

Figure 1.1 Focuses of research on resource and environmental policies

Table 1.1 shows the years that environmental agencies were established in each country, illustrating the complicated positions they occupy within government administration. Table 1.2 shows the years in which environmental acts and policies were introduced in each country, which traces part of the negotiation processes. 
The countries in the three leftmost columns of Tables 1.1 and 1.2 (the United States, Germany, and Japan) started industrialization relatively early and were also among the first to introduce environmental institutions and policies. In contrast, developing countries Taiwan, China, and Thailand have been relative latecomers in introducing environmental agencies and laws.

The two positive cases analyzed in Chapter 7 (the United States) and Chapter 8 (Germany) demonstrate that these countries secured enough time for negotiations among government agencies and with society and business before shifting toward new environmental reforms and policies (Table 1.2). Importantly, more than a decade of trial and error and failures resulting from scattered policies gave rise to a new combination of environmental policy ideas in these countries.

In the United States, for example, there have been proposals since the 1930s to create a Department of Conservation and a Department of Natural Resources to consolidate fragmented authority within the federal government, but none of these proposals have come to fruition. This is because the age-old concepts of "conservation" and "natural resources" as an integrative concept were accompanied by a number of institutional constraints (e.g., interagency conflicts). In addition, those concepts were not stated in public law as national policy and did not have sufficient legitimacy. However, in the 1960s, a new integrated concept of "environment"- a concept with fewer institutional constraints - emerged, and "environment" was also declared as national policy in the National Environmental Policy Act (NEPA) of 1969. This disrupted the persistence of previous political patterns and led to the consolidation of the authority of many federal agencies under the US Environmental Protection Agency (EPA) in 1970. Meanwhile, the German packaging waste policy introduced in 1991 highlights another innovative environmental policy. The DSD (Duales System Deutschland) system for collecting, sorting, and recycling packaging waste became a well-known model for environmental and waste policies for many countries around the world in the 1990s. Before introducing this system, it was considered difficult for German industry to establish a new recycling system. However, after a new idea to coordinate the policy with privatization schemes and create a new recycling industry, the DSD system quickly received industry support and realized its purpose in the 1990s.

With help from the "path dependence" perspective, the cases above analyze what played a significant role in blocking the consolidation of powers, and why and how it was overcome, making fragmented authorities integrated. Thus, historical policy formation means having a firm grasp of the characteristics of environmental policy as a latecomer (see also Kitagawa 2015; Oikawa 2013). The "path dependence" perspective gives insight also in the case of developing countries. Chapters 3 to 5 describe ineffective, diffused environmental policies implemented in China, Taiwan, and Thailand. These 


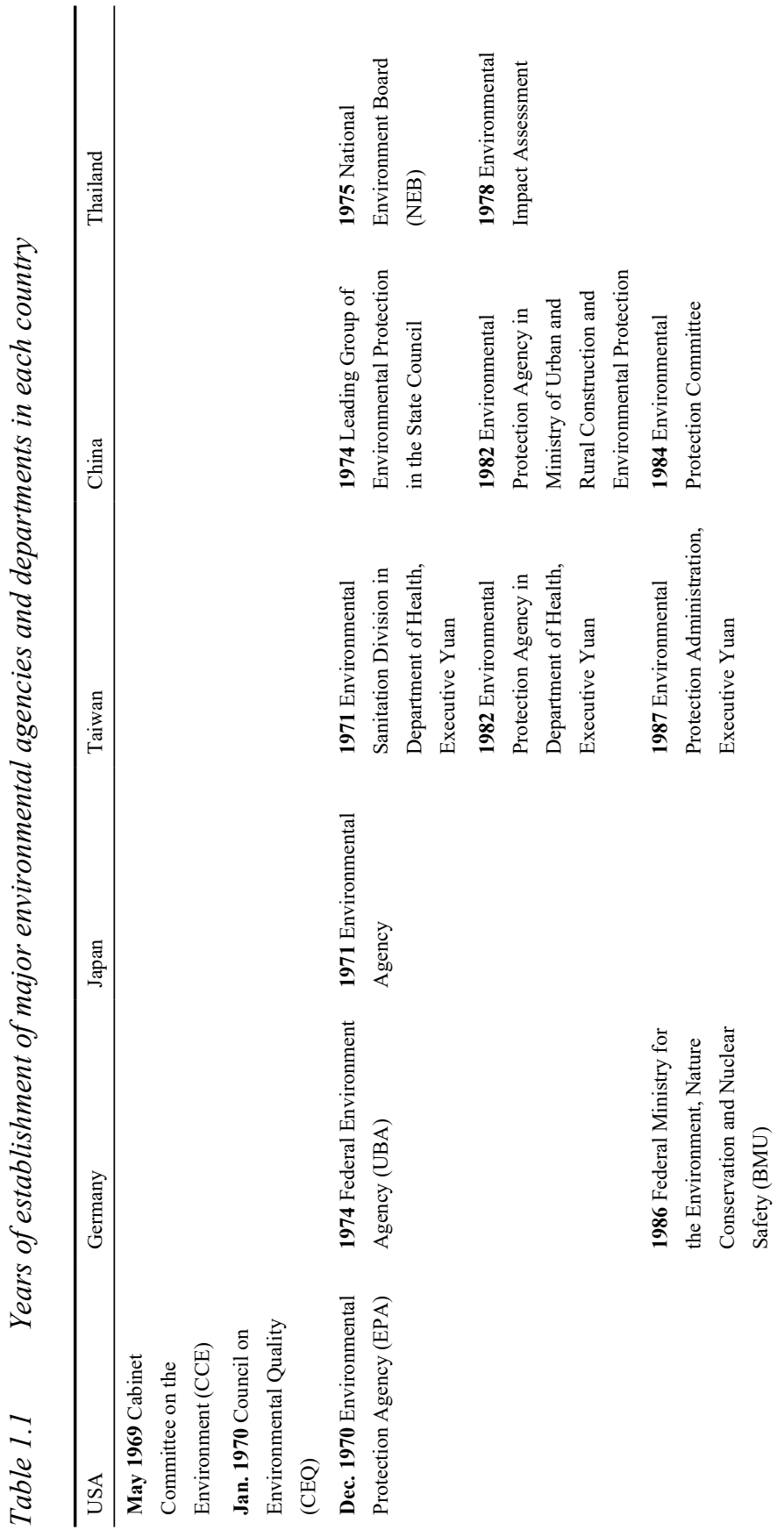




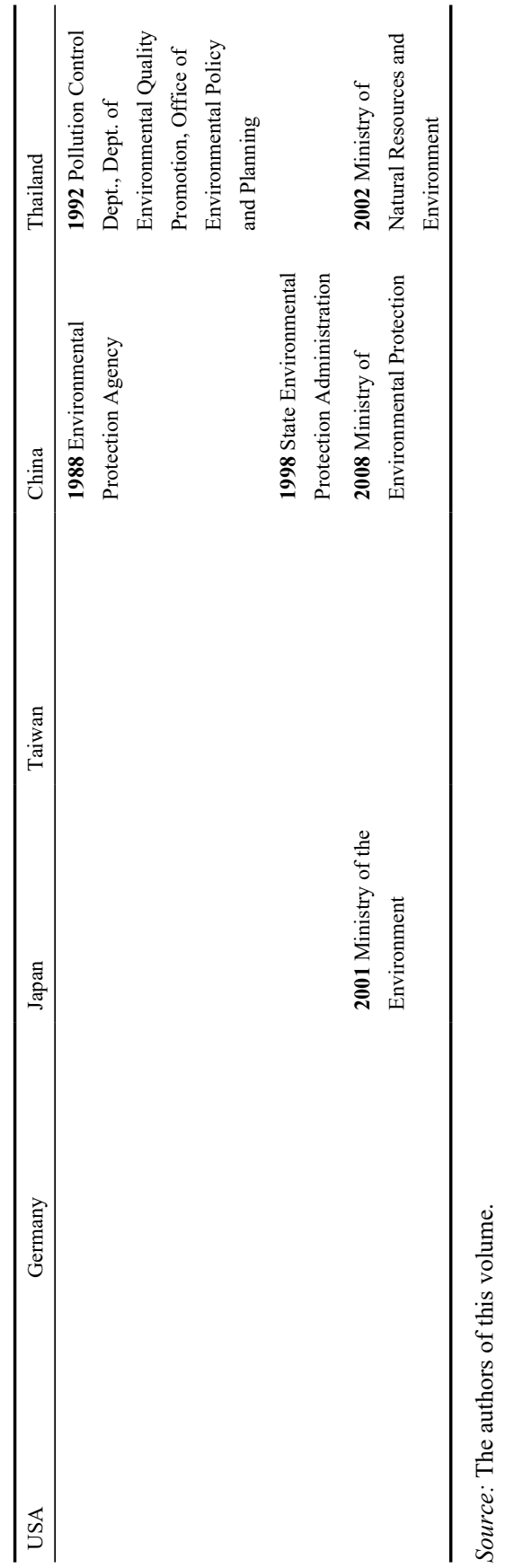




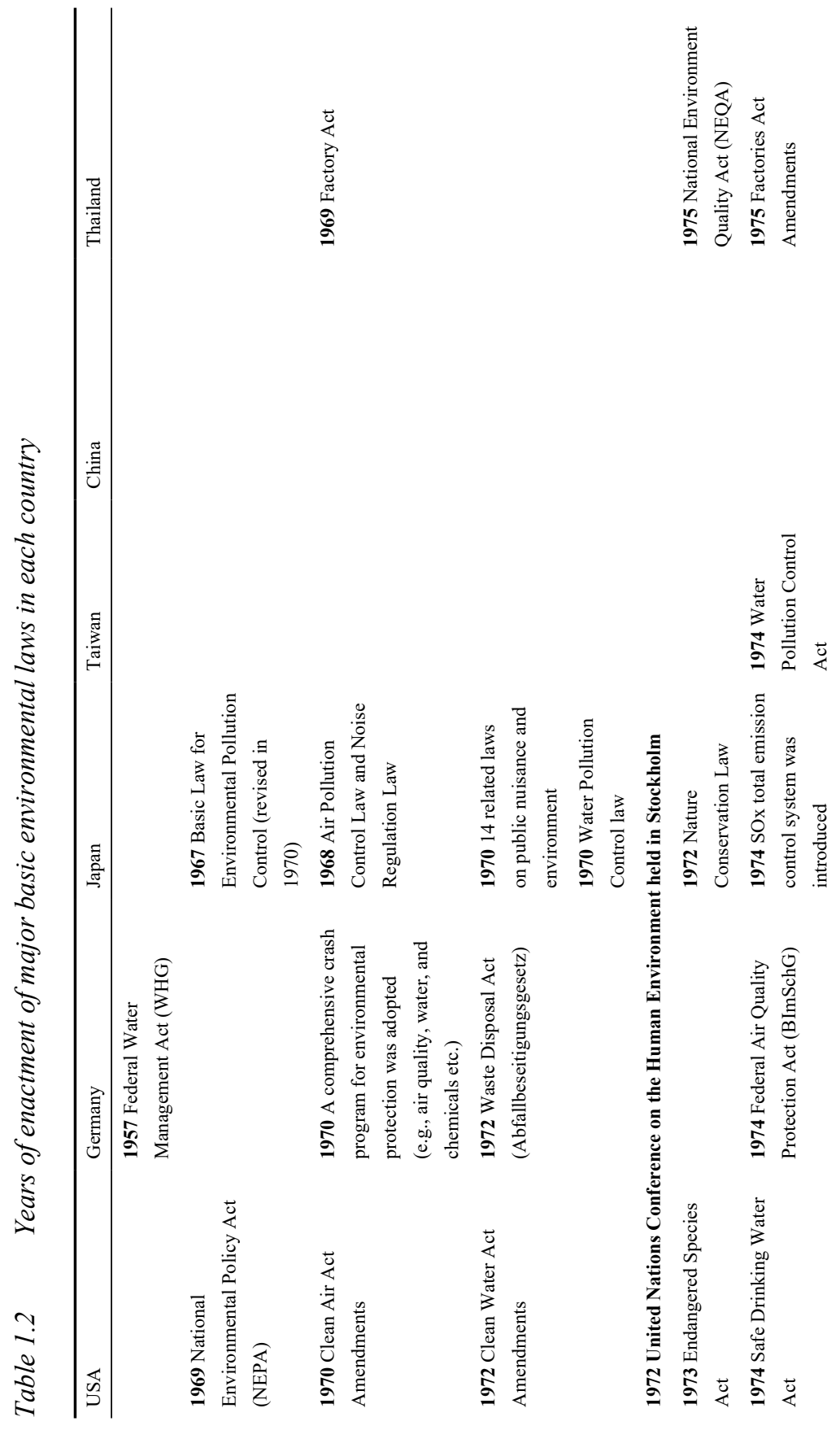




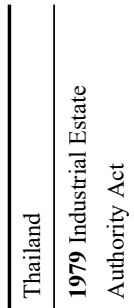
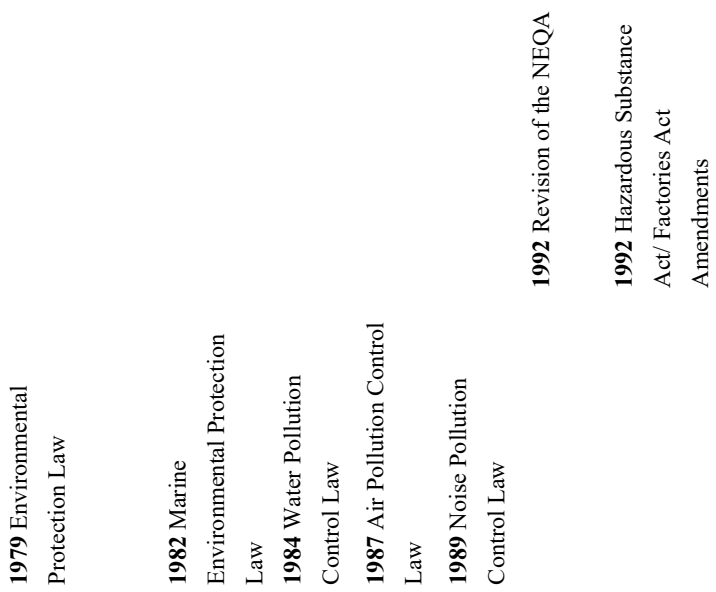

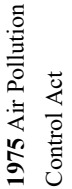

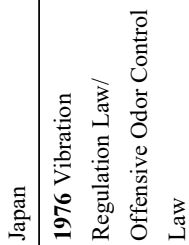
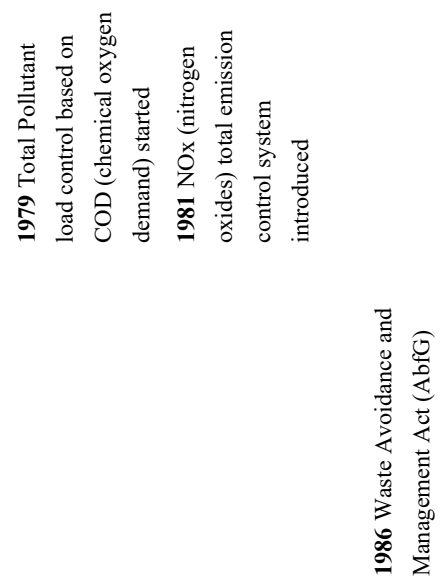

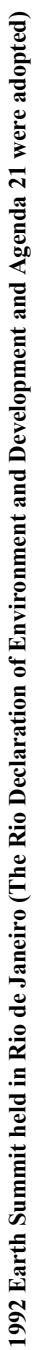




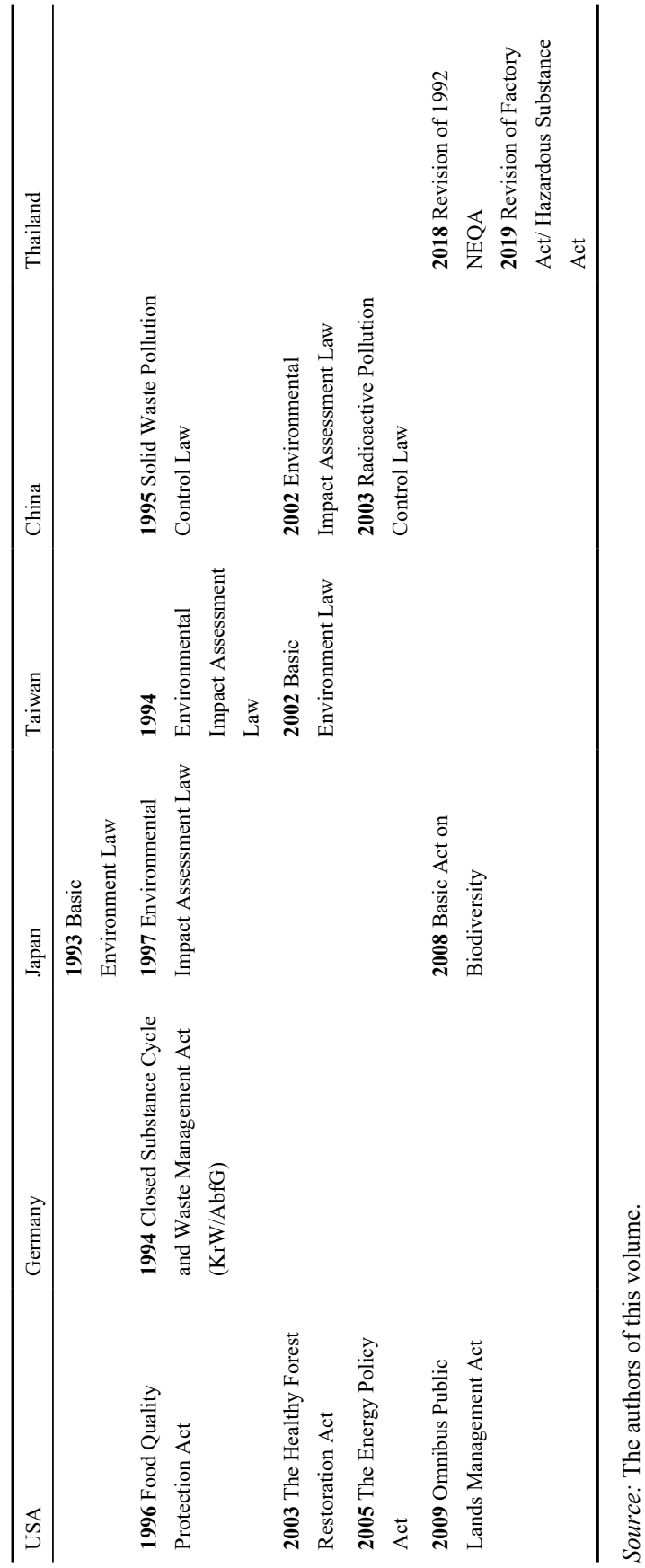


developing countries introduced their environmental laws and regulations to learn those of developed countries such as the United States, Germany, and Japan at a relatively early stage of industrial development (in China, after the open-door policy). Despite the possible advantageous timing in introducing environmental policies, their implementation and enforcement in developing countries often met obstacles due to a lack of policy coordination, resulting from diffused authority over environmental issues.

What are the obstacles to managing environmental policy in these developing countries? The analysis of each chapter suggests two main obstacles: fragmentation of government agencies and limited time for policy coordination and negotiation.

The analysis of China in Chapter 3 suggests the following points as initial problems in the development of environmental policy in China: (1) the control of information by the Communist Party of China and the Chinese government about the risk and harm to health, (2) the separation of environmental and health issues in the early stages of the policy formation process, and (3) the effect of a "developmental state" that prioritized economic development over environmental protection.

Chapter 4 (Taiwan) examines the Water Pollution Control Act of 1974 and the Air Pollution Control Act of 1975, the first environmental laws introduced in Taiwan. Although these laws were introduced during a relatively early phase of industrialization, they did not incorporate the important notion of the "living environment" to protect the common environment until 1992, and thus did not bring an end to the expansion of pollution until the mid-1980s because of limited zoning measures and insufficient regulations.

The analysis of Thailand in Chapter 5 highlights the problem of path dependence in the establishment of environmental agencies. Thailand adopted a "dual system" in which the Ministry of Industry and other environment-related agencies dealt with industrial pollution "independently." This system had no policy coordination with the industrial sector, thereby limiting the authority of the Pollution Control Department established in 1992 from controlling the emission of pollutants by factories until 2015 .

To summarize, environmental policy formation in these developing countries are characterized by laws and administrative systems that were selectively separated or fragmented into focused policy areas such as health, industrial development, and individual environmental issues. By synthesizing the analyses of each chapter, we found that it is necessary to coordinate policy with society in order to create and implement environmental policies successfully, and that the primary obstacle to this agenda in many developing countries is a lack of policy coordination. From our historical perspective highlighting the beginning phase of environmental policy formation, we also found that policy coordination requires a long time and many opportunities for change; thus, the 
length of the process was also an important factor influencing the success or failure of the policy outcome.

To ensure environmental quality, it is important to facilitate integrated, cross-sector coordination beyond the interests of individual agencies, government offices, and stakeholders in society. Through the analysis of environmental policy formation in this volume, we found that fragmented administration as well as diffused authorities were serious obstacles in the process of environmental policy formation and implementation. If adjustments and policy coordination with other policy areas and administrative authorities are not realized, the embodiment and implementation of policy becomes difficult. In fact, the environmental administration in many countries continues to evolve, even now, as described in this volume. Therefore, it is important to continue to analyze the historical development of policy formation and administrations, regardless of their failures or successes, from a long perspective.

\section{NOTE}

1. PM 2.5 indicates the amount of micro-particles mixed with a variety of pollutants that easily absorb into the alveoli of the lung.

\section{REFERENCES}

Bridge, Gavin and Tom Perreault (2009), "Environmental governance," in Noel Castree, David Demeritt, Diana Liverman, and Bruce Rohoads (eds.), A Companion to Environmental Geography, West Sussex, UK: Wiley-Blackwell, pp. 475-497.

Dryzek, John S. (1997), The Politics of the Earth: Environmental Discourses, Oxford: Oxford University Press.

Hardin, Garrett (1968), "The tragedy of the commons," Science, 162(3859), 1243-1248.

Kay, Adrian (2005), "A critique of the use of path dependency in policy studies," Public Administration, 83(3), 553-571.

Kitagawa, Susumu (2015), "Doitsu yōki-hōsō-rei no seiritsu katei: Kōchōkai o meguru dōkō o chūshin ni" ("Policymaking process of German packaging ordinance: The case of the public hearing on the packaging ordinance in 1990"), in Tadayoshi Terao (ed.), "Kōhatsusei" no poritikusu: Shigen kankyō seisaku no keisei katei (Politics of the environment: The formation of "latecomer" public policy), Chiba: Institute of Developing Economies, JETRO, pp. 153-188.

Lemos, Maria Carmen and Arun Agrawal (2006), "Environmental governance," Annual Review of Environment and Resources, 31, 297-325.

O'Conner, David (1994), Managing the Environment with Rapid Industrialization: Lessons from the East Asian Experiences, Paris: Development Centre of the OECD.

Oikawa, Hiroki (2013), "Nyūdīru kankyō gyōsei soshiki kaikaku zenshi: Hozen no fukusen-ka to shōchō no tairitsu" ("Conservation and organizational reform in the New Deal: How did the reform fail, and why?"), in Tadayoshi Terao (ed.), Kankyō seisaku no keisei katei: "Kaihatsu to kankyo" " no shiten kara (The formation of environmental policies in the process of economic development: From the viewpoint of 
"development and the environment"), Chiba: Institute of Development Economies, JETRO, pp. 175-194.

Pierson, Paul (2004), Politics in Time: History, Institutions, and Social Analysis, Princeton: Princeton University Press.

Sato, Jin (2013), "Towards the dynamic analysis of resources," in Jin Sato (ed.), Governance of Natural Resources: Uncovering the Social Purpose of Materials in Nature, Tokyo: United Nations University Press, pp. 1-14.

Sato, Jin (2019), Fukai tōchi: Tōnan Ajia no kangai to kokka kenryoku no shintō ("Deep governance: Irrigation and state power in Southeast Asia"), in Tadayoshi Terao (ed.), Shigen kankyō seisaku no keisei katei: "Kaihatsu to kankyō" no shiten kara (The formation process of resource and environmental policies in the process of economic development: From the viewpoint of "development and the environment"), Chiba: Institute of Developing Economies, JETRO, pp. 147-171.

Terao, Tadayoshi (2013), “'Kaihatsu to kankyō' no shiten niyoru kankyō seisaku keisei katē no hikaku kenkyū ni mukete" ("Towards a comparative study on environmental policy formation: From the viewpoint of 'development and the environment"'), in Tadayoshi Terao (ed.), Kankyō seisaku no keisei katei: "Kaihatsu to kankyō" no shiten kara (The formation of environmental policies in the process of economic development: From the viewpoint of "development and the environment"), Chiba: Institute of Developing Economies, JETRO, pp. 3-29.

Terao, Tadayoshi and Kenji Otsuka (eds.) (2007), Development of Environmental Policy in Japan and Asian Countries, Basingstoke and New York: Palgrave Macmillan. 